\title{
Polymorphisms in the SNCA Gene: Association with the Risk of Development of the Sporadic Form of Parkinson's Disease and the Level of SNCA Gene Expression in Peripheral Blood of Patients from Russia
}

\author{
Anelya Kh. Alieva ${ }^{1 *}$, Maria I. Shadrina ${ }^{1}$, Elena V. Filatova ${ }^{1}$, Vera V. Ustinova ${ }^{1}$, \\ Ekaterina Yu Fedotova ${ }^{2}$, Alexey V. Karabanov ${ }^{2}$, Sergey N. Illarioshkin ${ }^{2}$, Petr A. Slominsky ${ }^{1}$ \\ ${ }^{1}$ Institute of Molecular Genetics, Russian Academy of Sciences, Moscow, Russia; ${ }^{2}$ Research Centre of Neurology, Russian Academy \\ of Medical Sciences, Moscow, Russia. \\ Email: *anelja@img.ras.ru
}

Received August 20 $0^{\text {th }}, 2013$; revised September $18^{\text {th }}, 2013$; accepted October $15^{\text {th }}, 2013$

Copyright (C) 2013 Anelya Kh. Alieva et al. This is an open access article distributed under the Creative Commons Attribution License, which permits unrestricted use, distribution, and reproduction in any medium, provided the original work is properly cited.

\begin{abstract}
Parkinson's disease (PD) is one of the most common human neurodegenerative disorders caused by the loss of dopaminergic neurons in the brain. The $\alpha$-synuclein $(S N C A)$ gene is one of the most studied genes involved in the pathogenesis of PD. In our study, we conducted a genetic analysis of promoter and intron single-nucleotide polymorphisms (SNPs) in the SNCA gene. We also analyzed the association of genotypes of these SNPs with expression levels of $S N C A$ mRNA. One of four SNPs in the SNCA gene, and the rs 2736990 polymorphism, associates with the risk of the sporadic form of PD in Russian population. The risk of PD was increased almost twofold in carriers of allele C (odds ratios $=1.9$, 95\% confidence interval: $1.24-2.91, \mathrm{p}=0.003)$. However, no association was found between any of the genotypes of SNPs tested (rs2583988, rs2619363, rs2619364 and rs2736990) and alterations in SNCA levels. Our findings support the hypothesis that the rs2736990 polymorphism is associated with PD. SNPs rs2583988, rs2619363 and rs2619364 in the promoter region of the $S N C A$ gene themselves do not significantly influence the expression of $S N C A$. Most likely, $S N C A$ gene expression is a very complex process that is affected by different genetic and epigenetic factors.
\end{abstract}

Keywords: Parkinson's Disease; Expression Analysis; SNCA; SNP

\section{Introduction}

Parkinson's disease (PD) is one of the most common human neurodegenerative disorders after Alzheimer's disease. PD is morphologically characterized by progressive loss of dopaminergic neurons and in some cases by formation of fibrillar inclusions (Lewy bodies) with $\alpha$ synuclein $(S N C A)$ as its main component [1]. SNCA acts as a molecular chaperone and regulates protein-protein interactions in cells [2]. According to the latest data, $S N C A$ is required for the normal operation of a pre-synaptic complex by participating in the cyclic release of dopamine from the presynaptic vesicles [3-5]. SNCA was the first gene whose association with PD has been shown [6]. Currently, the SNCA gene is one of the most studied genes involved in the pathogenesis of PD. Several point

\footnotetext{
${ }^{*}$ Corresponding author.
}

mutations in the $S N C A$ gene and duplications and triplications of the genomic region containing SNCA were revealed. They are very rare and lead to the development of an autosomal dominant form of PD [7-11].

To date, a number of single-nucleotide polymorphisms (SNPs) in SNCA associated with a risk of the sporadic form of the disease have been revealed. According to genome-wide association studies (GWASs), more than five polymorphic variants were found to be associated with the risk of development of PD. One of the first of these SNPs identified in a genome-wide study was rs2736990. An association of this polymorphism with the risk of PD in patients from Europe and North America has been shown $[12,13]$. However, the risk of disease development did not exceed odds ratio $(\mathrm{OR})=1.4$. Thus, further verification of the results of GWASs in other population samples is required. 
Furthermore, polymorphic microsatellite Rep1 was found in the promoter region of $10 \mathrm{~kb}$ upstream of the SNCA transcription start site [14-16]. One of the microsatellite polymorphic variants, Rep1-261, has been associated with an increase in mRNA levels of SNCA in experiments with transgenic mice [17]. At the same time, the presence of the Rep1-259 allele has been demonstrated to correlate with a low level of SNCA mRNA in post mortem brain tissues of patients with PD [18]. It was shown that Rep1 was associated with rs2583988, rs2619363 and rs2619364, and that these polymorphic variants were in a strong linkage disequilibrium (LD: $\mathrm{r}^{2}=0.99$, D' $=$ 1.00) $[19,20]$. In studies of patients with PD from Europe (Belgium, Germany and Serbia), an association of these polymorphisms with the risk of PD was identified [2022].

Thereby, the aim of our study was to assess the role of rs2736990, rs2583988, rs2619363 and rs2619364 in the determination of genetic risk of development of PD in the Russian population. In addition, an analysis of the association between these SNPs and levels of SNCA transcripts in the peripheral blood of patients with PD from Russia was performed.

\section{Methods}

\subsection{Patients}

All patients (Russians residing in the European part of Russia) were diagnosed with PD at the Research Center of Neurology, Russian Academy of Medical Sciences (RAMS). All patients with PD were selected and studied according to the international Unified Parkinson's Disease Rating Scale (UPDRS) and Hoehn and Yahr scores $[23,24]$. The diagnosis of PD was based on the UK PD Brain Bank Criteria [25]. In this work, two groups of patients with PD were studied: 1) Patients with the sporadic form of PD at different stages of the disease (193 persons); 2) Newly diagnosed untreated patients with the sporadic form of PD (Hoehn and Yahr scores 1 - 2) (48 persons). In total, we recruited 241 sporadic patients with PD (115 males, 126 females). The mean age \pm SD at disease onset was $47.4 \pm 13.6$ years ( $30-74)$, and the mean age at enrollment was $56.5 \pm 13.8$ years $(32-83)$. Two hundred twenty-six neurologically normal age-matched individuals from the same population were studied as controls. All blood samples were collected with the informed consent of the investigated persons. The study was approved by the Ethics Committee of the Research Center of Neurology, RAMS.

\subsection{Genetic Analysis}

Isolation of genomic DNA from leukocytes was performed using the AxyPrepBlood Genomic DNA Mini- prep Kit (Axygen, Tewksbury, MA, USA) according to the manufacturer's recommendations.

To determine the genotypes of SNPs rs 2583988 , rs2619363, rs2619364 and rs2736990 in the SNCA gene, real-time TaqMan $^{\circledR}$ PCR assays (ID: C_16258278_10, C_16036895_10, C_3113461_10 and C_3208948_10, respectively) were used (Applied Biosystems, Foster City, CA, USA). The real-time PCR and thermal cycling were performed according to the manufacturer's instructions using StepOnePlus (Applied Biosystems). Each blood sample was analyzed in three independent runs for corrections of differences in sample quality.

\subsection{Expression Analysis}

For expression analysis, all blood samples were taken at 8:00 a.m. before eating and then stored for less than $2 \mathrm{~h}$ at $+4^{\circ} \mathrm{C}$ before isolation of RNA. Isolation of total RNA from whole blood was performed using the ZR WholeBlood Total RNA Kit ${ }^{\mathrm{TM}}$ (Zymo Research Corp., Irvine, CA, USA) according to the manufacturer's recommendations. Reverse transcription was carried out using the RevertAid $^{\mathrm{TM}}$ H Minus Reverse Transcriptase kit (Fermentas, Vilnius, Lithuania).

Relative levels of the expression of $S N C A$ gene and reference genes (POLR2F, PSMB6 and PSMA5) were analyzed using TaqMan real-time PCR. Transcripts of reference genes were amplified together with the $S N C A$ transcript to normalize gene expression data. Primers and probes were designed using Beacon Designer 7.02 software (Table 1).

Real-time reactions were conducted using the ANK-32 machine (Institute for Analytical Instrumentation, St. Petersburg, Russia) and PCR reagents (Syntol, Moscow, Russia). Thermal cycling was performed as follows: 1) $600 \mathrm{~s}$ at $95^{\circ} \mathrm{C}$ and 2) 45 cycles of $50 \mathrm{~s}$ at $95^{\circ} \mathrm{C}$ and $20 \mathrm{~s}$ at $60^{\circ} \mathrm{C}$.

It is necessary to note that each blood sample was analyzed in three independent runs for corrections of differences in sample quality and reverse transcription efficiency. Normalization was performed on the basis on amplification levels of reference genes. To assess the relative levels of gene expression, the method of comparison of amplification thresholds $\Delta \mathrm{Ct}$ was used [26].

\subsection{Statistical Analysis}

Estimation of OR and statistical significance of differences in allele and genotype distribution were performed using the software GraphPad InStat v 3.06 (GraphPad Software, Inc.).

The Hardy-Weinberg equilibrium calculator was used to calculate the compliance of genotype distribution in a population to the Hardy-Weinberg equilibrium using the 
Table 1. Primers and probes used in the expression analysis.

\begin{tabular}{ll}
\hline \multicolumn{1}{c}{ Gene } & \multicolumn{1}{c}{ Nucleotide sequences } \\
\hline SNCA & P: 5'-ROX-TGTTCTCTATGTAGGCTCCAA-RTQ2-3' \\
[GenBank: BC108275] & F: 5'-AGCAGGAAAGACAAAAGAGG-3' \\
& R: 5'-TTGCTCTTTGGTCTTCTCAG-3' \\
& P: 5'-FAM-CTTCATCCTCCTCCACATCATCAAAGTCGTCG-RTQ1-3' \\
POLR2F & F: 5'-ATGTCAGACAACGAGGACAATTTG-3' \\
[GenBank: DA372532.1] & R: 5'-TCTTCGGCATTCTCCAAGTCATC-3' \\
& P: 5'-FAM-AGCCGAGAAGTTTCCACTGGGACCACTATC-RTQ1-3' \\
PSMB6 & F: 5'-CGGAGGCGTTCACTCCAG-3' \\
[GenBank: BC000835] & R: 5'-TCGATTGGCGATGTAGGACC-3' \\
& P: 5'-AGCCATCAAGTCTTCACTCATCATCCTC-RTQ1-3' \\
PSMA5 & F: 5'-AGAAGTTTACCACAAGTCTATGAC-3' \\
[GenBank: AK304448.1] & R: 5'-CATTCAGCTTCTCCTCCATTAC-3' \\
\hline
\end{tabular}

$\mathrm{P}$ - probe, $\mathrm{F}$-forward primer, $\mathrm{R}$ - reverse primer.

$\chi^{2}$ method [27].

Analysis of the expression levels and the calculation of the median $\Delta \mathrm{Ct}$ were performed using the software MS Excel 2010 (Microsoft).

Significance of the differences in expression levels of different genotypes was determined by the KruskalWallis ANOVA method using the software package Statistica for Windows 8.0 (StatSoft, Inc. 2007).

\section{Results}

\subsection{Genetic Analysis}

In this study, we analyzed four SNPs, three of which were located in the promoter region of the SNCA gene (rs2619363, rs2619364 and rs2583988); SNP rs2736990 was located in the fourth intron of the same gene. For each studied SNP, the genotype distribution is consistent with the Hardy-Weinberg equilibrium (for rs2583988: $\chi^{2}$ $=0.23$ and $\mathrm{p}=0.63$; for rs2619363: $\chi^{2}=0.01$ and $\mathrm{p}=$ 0.92; for rs 2619364: $\chi^{2}=0.08$ and $\mathrm{p}=0.77$; for rs2736990: $\chi^{2}=1.32$ and $p=0.25$ ). Genotype data are shown in Table 2.

The presented data show no statistically significant differences in the genotype distribution of the three SNPs (rs2583988, rs2619363 and rs2619364), located in the SNCA promoter region, between patients with PD and the population control. However, a statistically significant difference was shown in the genotype distribution of rs2736990 between the studied groups. Genotype CC predominates in patients with PD and the presence of the $\mathrm{C}$ allele is associated with an increased risk of the development of PD.

\subsection{Analysis of mRNA Levels of SNCA Transcripts}

We investigated whether the relative mRNA levels of the SNCA gene depend on the genotypes of rs 2583988 , rs2619363, rs2619364 and rs2736990 in patients with PD with early stages of the disorder. The results are summarized in Table 3.

Carriers of the rare TT genotype (rs2583988 and rs2619363) and GG genotype (rs2619364) have higher relative mRNA levels of SNCA gene compared with more common genotypes of these SNPs (Table 3) in patients with PD. On the other hand, it was found that the TT genotype of rs2736990 is associated with lower relative expression levels of SNCA mRNA than genotypes $\mathrm{CC}$ and $\mathrm{CT}$. However, the observed differences are not statistically significant.

It should be noted that the data on the relative expression levels for rs2583988 and rs2619364 coincide. Such coincidence is observed in genotype frequencies of these polymorphisms (Table 2). Perhaps this is because these two SNPs are in complete linkage disequilibrium.

\section{Discussion}

We carried out a genotype analysis of rs2736990, for which an association with the development of PD, has been repeatedly shown. Our findings are consistent with the GWAS observations [13,28,29]. As can be seen from Table 2, we succeeded in showing an association of rs2736990 in the $S N C A$ gene with the risk of the sporadic form of PD in the Russian population.

We obtained OR $=1.9(95 \%$ CI: $1.24-2.91, \mathrm{p}=$ 0.003), which reflects an increased risk of PD almost twofold in carriers of allele C. These findings are also supported by results of genome-wide studies by SimónSánchez and Edwards $(\mathrm{OR}=1.29$ at $\mathrm{p}=0.01, \mathrm{OR}=1.27$ at $\mathrm{p}=6.17 \times 10-13$ and $\mathrm{OR}=1.23$ and $\mathrm{p}=2.24 \times 10-$ 16), obtained in large groups of patients with PD [12, 30,31]. Furthermore, during analysis of the expression levels of $S N C A$ transcripts, it was shown that these levels were higher in carriers with genotypes CC and CT in rs2736990 than that in patients carrying the TT genotype, 
Table 2. Allelic and genotype frequencies of SNPs in SNCA.

\begin{tabular}{|c|c|c|c|c|c|c|c|}
\hline \multirow[b]{2}{*}{ rs2583988 } & \multicolumn{2}{|c|}{ Alleles N (\%) } & \multicolumn{3}{|c|}{ Genotypes N (\%) } & \multirow{2}{*}{$\begin{array}{c}\text { Odds Ratio }(95 \% \\
\text { confidence interval, } \mathrm{CI}) \\
(\mathrm{CC}+\mathrm{CT}) / \mathrm{TT}\end{array}$} & \multirow[t]{2}{*}{$\mathrm{p}$} \\
\hline & $\mathrm{C}$ & $\mathrm{T}$ & $\mathrm{CC}$ & $\mathrm{CT}$ & $\mathrm{TT}$ & & \\
\hline Population control (226) & $207(0.66)$ & $107(0.34)$ & $119(0.52)$ & $88(0.40)$ & $19(0.08)$ & $0.91(0.48-1.74)$ & 0.87 \\
\hline rs2619363 & G & $\mathrm{T}$ & GG & GT & TT & $(\mathrm{GG}+\mathrm{GT}) / \mathrm{TT}$ & \\
\hline Population control (226) & $209(0.66)$ & $108(0.34)$ & $118(0.52)$ & $91(0.40)$ & $17(0.08)$ & $0.88(0.45-1.74)$ & 0.73 \\
\hline rs2619364 & A & G & AA & $\mathrm{AG}$ & GG & $(\mathrm{AA}+\mathrm{AG}) / \mathrm{GG}$ & \\
\hline Patients with sporadic form of PD (240) & $218(0.66)$ & $115(0.34)$ & $125(0.52)$ & $93(0.39)$ & $22(0.09)$ & \multirow{2}{*}{$0.91(0.48-1.73)$} & \multirow{2}{*}{0.87} \\
\hline Population control (226) & $207(0.66)$ & $109(0.34)$ & $117(0.52)$ & $90(0.40)$ & $19(0.08)$ & & \\
\hline rs2736990 & $\mathrm{C}$ & $\mathrm{T}$ & $\mathrm{CC}$ & $\mathrm{CT}$ & $\mathrm{TT}$ & $(\mathrm{CC}+\mathrm{CT}) / \mathrm{TT}$ & \\
\hline Patients with sporadic form of PD (228) & $181(0.57)$ & $136(0.43)$ & $92(0.40)$ & $89(0.39)$ & $47(0.21)$ & \multirow{2}{*}{$1.9(1.24-2.91)$} & \multirow{2}{*}{0.003} \\
\hline Population control (224) & $150(0.46)$ & $176(0.54)$ & $48(0.21)$ & $102(0.46)$ & $74(0.33)$ & & \\
\hline
\end{tabular}

Table 3. Relative mRNA levels of SNCA transcripts and tested SNPs genotypes in patients with PD.

\begin{tabular}{|c|c|c|c|c|}
\hline SNP & & Genotypes & & $\mathrm{p}$ \\
\hline rs 2583988 & $\mathrm{CC}$ & CT & TT & \\
\hline $\begin{array}{l}\text { Relative expression mRNA level } \\
\text { of } S N C A\end{array}$ & $\begin{array}{c}-5.97 \\
(-8.01--2.77)\end{array}$ & $\begin{array}{c}-5.58 \\
(-6.80--3.44)\end{array}$ & $\begin{array}{c}-5.34 \\
(-6.28--4.33)\end{array}$ & 0.74 \\
\hline rs2619363 & GG & GT & $\mathrm{TT}$ & \\
\hline $\begin{array}{l}\text { Relative expression mRNA level } \\
\text { of } S N C A\end{array}$ & $\begin{array}{c}-5.80 \\
(-8.01--2.77)\end{array}$ & $\begin{array}{c}-5.57 \\
(-6.80--2.91)\end{array}$ & $\begin{array}{c}-5.65 \\
(-6.87--4.33)\end{array}$ & 0.75 \\
\hline rs2619364 & $\mathrm{AA}$ & $\mathrm{AG}$ & GG & \\
\hline $\begin{array}{l}\text { Relative expression mRNA level } \\
\text { of } S N C A\end{array}$ & $\begin{array}{c}-5.97 \\
(-8.01--2.77)\end{array}$ & $\begin{array}{c}-5.58 \\
(-6.80--3.44)\end{array}$ & $\begin{array}{c}-5.34 \\
(-6.28--4.33)\end{array}$ & 0.74 \\
\hline rs2736990 & $\mathrm{CC}$ & $\mathrm{CT}$ & TT & \\
\hline $\begin{array}{l}\text { Relative expression mRNA level } \\
\text { of } S N C A\end{array}$ & $\begin{array}{c}-5.40 \\
(-6.28--2.92)\end{array}$ & $\begin{array}{c}-5.86 \\
(-7.73--2.77)\end{array}$ & $\begin{array}{c}-7.18 \\
(-8.92--5.05)\end{array}$ & 0.23 \\
\hline
\end{tabular}

although the differences were not statistically significant. As mentioned above, rs2736990 is located in the center of the fourth intron of the $S N C A$ gene. Studies of patients with PD from Germany and Japan demonstrated that there was a linkage between intron 4 and the 5'- and 3'untranslated regions (UTRs) of SNCA [32,33]. Perhaps rs2736990 is linked with the functionally significant variant in the $3^{\prime}$ or 5 ' UTRs of the gene that may influence the expression of $S N C A$.

Rs2583988, rs2619363 and rs2619364, located in the SNCA gene and linked with Rep1, were also genotyped in this study [20,21]. Our study showed no association of these SNPs and the development of PD in Russian patients $(\mathrm{OR}=0.88-0.91,95 \% \mathrm{CI}: 0.45-1.74, \mathrm{p}=0.73$ $0.87)$. These data are consistent with the investigation of Irish patients with PD, where no association among rs2583988, rs2619363 and rs2619364 and the development of $\mathrm{PD}$ was found $(\mathrm{OR}=1.14-1.18,95 \% \mathrm{CI}$ : 0.76 1.78) [19]. However, higher relative levels of $S N C A$
mRNA were observed in PD patients carrying the TT genotype (for rs2583988 and rs2619363) and the GG genotype (for rs2619364) in peripheral blood compared with carriers of the $\mathrm{C}$ allele in rs2583988, G-in rs2619363 and A-in rs2619364. Although no association of any change in the expression levels of the SNCA gene with SNPs rs2583988 and rs2619363 was found in the work by Linnertz, at the same time, an association between changes in SNCA gene expression and Rep1, linked with these polymorphisms, was demonstrated [18]. It seems like that the three SNPs in the promoter region of the $S N C A$ gene have an insignificant effect on the expression of $S N C A$.

It is possible that rs2736990 or/and an unknown linked causal sequence variant may regulate transcription of $S N C A$ either directly or indirectly through coordination with transcriptional enhancers and repressors. The results of our study improved our understanding of the contribution of genetic variants within the SNCA locus to spo- 
Polymorphisms in the SNCA Gene: Association with the Risk of Development of the Sporadic Form of Parkinson's Disease and the Level of SNCA Gene Expression in Peripheral Blood of Patients from Russia

radic PD. Better knowledge of the molecular mechanisms that modulate $S N C A$ gene expression, may lead to novel therapeutic approaches based on changes in $S N C A$ levels. Further, this SNP rs2736990 in SNCA gene may be included into the panel of biomarkers for the assessment of the individual risk of PD development.

\section{Acknowledgements}

This work was supported by the Russian Foundation for Basic Research (projects no. 12-04-31091, 12-04-01183a), as well as by programs of the Russian Academy of Sciences (Molecular and Cellular Biology, Fundamental Sciences for Medicine), state contracts (no. 16.740.11. $0630,8605,8851,14.512 .11 .0043$ and 14.122.13.641MK).

\section{REFERENCES}

[1] L. M. de Lau and M. M. Breteler, "Epidemiology of Parkinson's Disease," The Lancet Neurology, Vol. 5, No. 6, 2006, pp. 525-535. http://dx.doi.org/10.1016/S1474-4422(06)70471-9

[2] L. Yavich, H. Tanila, S. Vepsalainen and P. Jakala, "Role of Alpha-Synuclein in Presynaptic Dopamine Recruitment," The Journal of Neuroscience, Vol. 24, No. 49, 2004, pp. 11165-11170.

[3] J. Burre, M. Sharma, T. Tsetsenis, V. Buchman, M. R. Etherton and T. C. Sudhof, "Alpha-Synuclein Promotes Snare-Complex Assembly in Vivo and in Vitro," Science, Vol. 329, No. 5999, 2010, pp. 1663-1667. http://dx.doi.org/10.1126/science.1195227

[4] B. K. Choi, M. G. Choi, J. Y. Kim, Y. Yang, Y. Lai, D. H. Kweon, N. K. Lee and Y. K. Shin, "Large Alpha-Synuclein Oligomers Inhibit Neuronal Snare-Mediated Vesicle Docking," Proceedings of the National Academy of Sciences of USA, Vol. 110, No. 10, 2013, pp. 4087-4092. http://dx.doi.org/10.1073/pnas.1218424110

[5] J. J. McCarthy, C. Linnertz, L. Saucier, J. R. Burke, C. M. Hulette, K. A. Welsh-Bohmer and O. Chiba-Falek, "The Effect of SNCA 3' Region on the Levels of SNCA-112 Splicing Variant," Neurogenetics, Vol. 12, No. 1, 2011, pp. 59-64. http://dx.doi.org/10.1007/s10048-010-0263-4

[6] M. H. Polymeropoulos, C. Lavedan, E. Leroy, S. E. Ide, A. Dehejia, A. Dutra, B. Pike, H. Root, J. Rubenstein, R. Boyer, E. S. Stenroos, S. Chandrasekharappa, A. Athanassiadou, T. Papapetropoulos, W. G. Johnson, A. M. Lazzarini, R. C. Duvoisin, G. Di Iorio, L. I. Golbe and R. L. Nussbaum, "Mutation in the Alpha-Synuclein Gene Identified in Families with Parkinson's Disease," Science, Vol. 276, No. 5321, 1997, pp. 2045-2047. http://dx.doi.org/10.1126/science.276.5321.2045

[7] M. C. Chartier-Harlin, J. Kachergus, C. Roumier, V. Mouroux, X. Douay, S. Lincoln, C. Levecque, L. Larvor, J. Andrieux, M. Hulihan, N. Waucquier, L. Defebvre, P. Amouyel, M. Farrer and A. Destee, "Alpha-Synuclein Locus Duplication as a Cause of Familial Parkinson's
Disease," Lancet, Vol. 364, No. 9440, 2004, pp. 1167 1169. http://dx.doi.org/10.1016/S0140-6736(04)17103-1

[8] A. B. Singleton, M. Farrer, J. Johnson, A. Singleton, S. Hague, J. Kachergus, M. Hulihan, T. Peuralinna, A. Dutra, R. Nussbaum, S. Lincoln, A. Crawley, M. Hanson, D. Maraganore, C. Adler, M. R. Cookson, M. Muenter, M. Baptista, D. Miller, J. Blancato, J. Hardy and K. GwinnHardy, "Alpha-Synuclein Locus Triplication Causes Parkinson's Disease," Science, Vol. 302, No. 5646, 2003, pp. 841. http://dx.doi.org/10.1126/science.1090278

[9] M. C. Chartier-Harlin, J. Kachergus, C. Roumier, et al., "Alpha-Synuclein Locus Duplication as a Cause of Familial Parkinson's Disease," Lancet, Vol. 364, No. 9440, 2004, pp. 1167-1169. http://dx.doi.org/10.1016/S0140-6736(04)17103-1

[10] K. Nishioka, S. Hayashi, M. J. Farrer, et al., "Clinical Heterogeneity of Alpha-Synuclein Gene Duplication in Parkinson's Disease," Annals of Neurology, Vol. 59, No. 2, 2006, pp. 298-309.

[11] T. Sekine, H. Kagaya, M. Funayama, Y. Li, H. Yoshino, H. Tomiyama and N. Hattori, "Clinical Course of the First Asian Family with Parkinsonism Related to SNCA Triplication," Movement Disorders, Vol. 25, No. 16, 2010, pp. 2871-2875. http://dx.doi.org/10.1002/mds.23313

[12] T. L. Edwards, W. K. Scott, C. Almonte, A. Burt, E. H. Powell, G. W. Beecham, L. Wang, S. Züchner, I. Konidari, G. Wang, C. Singer, F. Nahab, B. Scott, J. M. Stajich, M. Pericak-Vance, J. Haines, J. M. Vance and E. R. Martin, "Genome-Wide Association Study Confirms SNPs in SNCA and the Mapt Region as Common Risk Factors for Parkinson Disease," Annals of Human Genetics, Vol. 74, No. 2, 2010, pp. 97-109. http://dx.doi.org/10.1111/j.1469-1809.2009.00560.x

[13] J. Simon-Sanchez, C. Schulte, J. M. Bras, M. Sharma, J. R. Gibbs, D. Berg, C. Paisan-Ruiz, P. Lichtner, S. W. Scholz, D. G. Hernandez, R. Kruger, M. Federoff, C. Klein, A. Goate, J. Perlmutter, M. Bonin, M. A. Nalls, T. Illig, C. Gieger, H. Houlden, M. Steffens, M. S. Okun, B. A. Racette, M. R. Cookson, K. D. Foote, H. H. Fernandez, B. J. Traynor, S. Schreiber, S. Arepalli, R. Zonozi, K. Gwinn, M. van der Brug, G. Lopez, S. J. Chanock, A. Schatzkin, Y. Park, A. Hollenbeck, J. Gao, X. Huang, N. W. Wood, D. Lorenz, G. Deuschl, H. Chen, O. Riess, J. A. Hardy, A. B. Singleton and T. Gasser, "Genome-Wide Association Study Reveals Genetic Risk Underlying Parkinson's Disease," Nature Genetics, Vol. 41, No. 12, 2009, pp. 1308-1312. http://dx.doi.org/10.1038/ng.487

[14] E. K. Tan, T. Matsuura, S. Nagamitsu, M. Khajavi, J. Jankovic and T. Ashizawa, "Polymorphism of Nacp-Rep1 in Parkinson's Disease: An Etiologic Link with Essential Tremor?" Neurology, Vol. 54, No. 5, 2000, pp. 1195-1198. http://dx.doi.org/10.1212/WNL.54.5.1195

[15] Y. Xia, H. A. Rohan de Silva, B. L. Rosi, L. H. Yamaoka, J. B. Rimmler, M. A. Pericak-Vance, A. D. Roses, X. Chen, E. Masliah, R. DeTeresa, A. Iwai, M. Sundsmo, R. G. Thomas, C. R. Hofstetter, E. Gregory, L. A. Hansen, R. Katzman, L. J. Thal and T. Saitoh, "Genetic Studies in Alzheimer's Disease with an Nacp/Alpha-Synuclein Polymorphism," Annals of Neurology, Vol. 40, No. 2, 1996, 
pp. 207-215. http://dx.doi.org/10.1002/ana.410400212

[16] O. Chiba-Falek, J. W. Touchman and R. L. Nussbaum, "Functional Analysis of Intra-Allelic Variation at NacpRep1 in the Alpha-Synuclein Gene," Human Genetics, Vol. 113, No. 5, 2003, pp. 426-431.

http://dx.doi.org/10.1007/s00439-003-1002-9

[17] K. D. Cronin, D. Ge, P. Manninger, C. Linnertz, A. Rossoshek, B. M. Orrison, D. J. Bernard, O. M. El-Agnaf, M. G. Schlossmacher, R. L. Nussbaum and O. ChibaFalek, "Expansion of the Parkinson Disease-Associated SNCA-Rep1 Allele Upregulates Human Alpha-Synuclein in Transgenic Mouse Brain," Human Molecular Genetics, Vol. 18, No. 17, 2009, pp. 3274-3285. http://dx.doi.org/10.1093/hmg/ddp265

[18] C. Linnertz, L. Saucier, D. Ge, K. D. Cronin, J. R. Burke, J. N. Browndyke, C. M. Hulette, K. A. Welsh-Bohmer and O. Chiba-Falek, "Genetic Regulation of Alpha-Synuclein Mrna Expression in Various Human Brain Tissues," PLoS ONE, Vol. 4, No. 10, 2009, p. e7480. http://dx.doi.org/10.1371/journal.pone.0007480

[19] O. A. Ross, D. Gosal, J. T. Stone, S. J. Lincoln, M. G. Heckman, G. B. Irvine, J. A. Johnston, J. M. Gibson, M. J. Farrer and T. Lynch, "Familial Genes in Sporadic Disease: Common Variants of Alpha-Synuclein Gene Associate with Parkinson's Disease," Mechanisms of Ageing and Development, Vol. 128, No. 5-6, 2007, pp. 378-382. http://dx.doi.org/10.1016/i.mad.2007.04.002

[20] S. Winkler, J. Hagenah, S. Lincoln, M. Heckman, K. Haugarvoll, K. Lohmann-Hedrich, V. Kostic, M. Farrer and C. Klein, "Alpha-Synuclein and Parkinson Disease Susceptibility," Neurology, Vol. 69, No. 18, 2007, pp. 1745-1750. http://dx.doi.org/10.1212/01.wnl.0000275524.15125.f4

[21] P. Pals, S. Lincoln, J. Manning, M. Heckman, L. Skipper, M. Hulihan, M. Van den Broeck, T. De Pooter, P. Cras, J. Crook, C. Van Broeckhoven and M. J. Farrer, "AlphaSynuclein Promoter Confers Susceptibility to Parkinson's Disease," Annals of Neurology, Vol. 56, No. 4, 2004, pp. 591-595.http://dx.doi.org/10.1002/ana.20268

[22] L. Brighina, R. Frigerio, N. K. Schneider, T. G. Lesnick, M. de Andrade, J. M. Cunningham, M. J. Farrer, S. J. Lincoln, H. Checkoway, W. A. Rocca and D. M. Maraganore, "Alpha-Synuclein, Pesticides, and Parkinson Disease: A Case-Control Study," Neurology, Vol. 70, No. 16 Pt 2, 2008, pp. 1461-1469. http://dx.doi.org/10.1212/01.wnl.0000304049.31377.f2

[23] B. S. Fahn, R. Elton and M. O. T. U. D. Committee, "Unified Parkinson's Disease Rating Scale," Recent Developments in Parkinson's Disease, Macmillan Health Care Information, Florham Park, 1987, pp. 153-164.

[24] C. G. Goetz, W. Poewe, O. Rascol, C. Sampaio, G. T. Stebbins, C. Counsell, N. Giladi, R. G. Holloway, C. G. Moore, G. K. Wenning, M. D. Yahr and L. Seidl, "Movement Disorder Society Task Force Report on the Hoehn and Yahr Staging Scale: Status and Recommendations," Movement Disorders, Vol. 19, No. 9, 2004, pp. 10201028. http://dx.doi.org/10.1002/mds.20213

[25] A. J. Hughes, S. E. Daniel, L. Kilford and A. J. Lees,
“Accuracy of Clinical Diagnosis of Idiopathic Parkinson's Disease: A Clinico-Pathological Study of 100 Cases," Journal of Neurology, Neurosurgery \& Psychiatry, Vol. 55, No. 3, 1992, pp. 181-184. http://dx.doi.org/10.1136/jnnp.55.3.181

[26] Applied Biosystems, "User Bulletin No 2: Abi Prism 7700 Sequence Detection System," 2001.

[27] S. Rodriguez, T. R. Gaunt and I. N. M. Day, "HardyWeinberg Equilibrium Testing of Biological Ascertainment for Mendelian Randomization Studies," In: Editor, Eds., Book Hardy-Weinberg Equilibrium Testing of Biological Ascertainment for Mendelian Randomization Studies, publishing house, city, 2009, pp. .

[28] T. L. Edwards, W. K. Scott, C. Almonte, A. Burt, E. H. Powell, G. W. Beecham, L. Wang, S. Zuchner, I. Konidari, G. Wang, C. Singer, F. Nahab, B. Scott, J. M. Stajich, M. Pericak-Vance, J. Haines, J. M. Vance and E. R. Martin, "Genome-Wide Association Study Confirms SNPs in SNCA and the Mapt Region as Common Risk Factors for Parkinson Disease," Annals of Human Genetics, Vol. 74, No. 2, 2010, pp. 97-109. http://dx.doi.org/10.1111/j.1469-1809.2009.00560.x

[29] J. Simon-Sanchez, J. J. van Hilten, B. van de Warrenburg, B. Post, H. W. Berendse, S. Arepalli, D. G. Hernandez, R. M. de Bie, D. Velseboer, H. Scheffer, B. Bloem, K. D. van Dijk, F. Rivadeneira, A. Hofman, A. G. Uitterlinden, P. Rizzu, Z. Bochdanovits, A. B. Singleton and P. Heutink, "Genome-Wide Association Study Confirms Extant Pd Risk Loci among the Dutch," European Journal of Human Genetics, Vol. 19, No. 6, 2011, pp. 655-661. http://dx.doi.org/10.1038/ejhg.2010.254

[30] J. Simon-Sanchez, C. Paisan-Ruiz, J. Bras, S. Scholz, R. Gibbs, T. Gasser and A. B. Singleton, "Genome-Wide Analysis in Parkinson's Disease," Proceedings European Human Genetics Conference, Vol. 17, Suppl. 2, Vienna, Austria, May 2009, p. 39.

[31] J. Simón-Sánchez, C. Schulte, J. M. Bras, M. Sharma, J. R. Gibbs, D. Berg, C. Paisan-Ruiz, P. Lichtner, S. W. Scholz, D. G. Hernandez, R. Krüger, M. Federoff, C. Klein, A. Goate, J. Perlmutter, M. Bonin, M. A. Nalls, T. Illig, C. Gieger, H. Houlden, M. Steffens, M. S. Okun, B. A. Racette, M. R. Cookson, K. D. Foote, H. H. Fernandez, B. J. Traynor, S. Schreiber, S. Arepalli, R. Zonozi, K. Gwinn, M. V. D. Brug, G. Lopez, S. J. Chanock, A. Schatzkin, Y. Park, A. Hollenbeck, J. Gao, X. Huang, N. W. Wood, D. Lorenz, G. Deuschl, H. Chen, O. Riess, J. A. Hardy, A. B. Singleton and T. Gasser, "Genome-Wide Association Study Reveals Genetic Risk Underlying Parkinson's Disease," Nature Genetics, Vol. 41, No. 12, 2009, pp. 1308-1314. http://dx.doi.org/10.1038/ng.487

[32] I. Mizuta, W. Satake, Y. Nakabayashi, C. Ito, S. Suzuki, Y. Momose, Y. Nagai, A. Oka, H. Inoko, J. Fukae, Y. Saito, M. Sawabe, S. Murayama, M. Yamamoto, N. Hattori, M. Murata and T. Toda, "Multiple Candidate Gene Analysis Identifies Alpha-Synuclein as a Susceptibility Gene for Sporadic Parkinson's Disease," Human Molecular Genetics, Vol. 15, No. 7, 2006, pp. 1151-1158. http://dx.doi.org/10.1093/hmg/dd1030

[33] J. C. Mueller, J. Fuchs, A. Hofer, A. Zimprich, P. Licht- 
ner, T. Illig, D. Berg, U. Wullner, T. Meitinger and T. Gasser, "Multiple Regions of Alpha-Synuclein Are Associated with Parkinson's Disease," Annals of Neurology,

\section{List of the Abbreviations}

PD_Parkinson's disease,

SNP — single-nucleotide polymorphism,

GWAS — genome — wide associated study,
Vol. 57, No. 4, 2005, pp. 535-541.

http://dx.doi.org/10.1002/ana.20438
OR - odds ratio,

$\mathrm{CI}$-confidence interval,

UTR - untranslated region. 